\title{
TOWARDS AN EFFECTIVE LEGAL AND REGULATORY FRAMEWORK FOR PUBLIC-PRIVATE PARTNERSHIPS IN MALAYSIA: LESSONS FROM THE SOUTH AFRICAN EXPERIENCE
}

\author{
Mubarak. T. Adekilekun* \\ C. C. Gan ${ }^{* *}$
}

\begin{abstract}
In order to ensure a sustained cooperation with both the local and international private investors in Malaysia especially in the provision of public infrastructure, the government needs to develop very strong legal and regulatory capabilities which will help in providing stable institutional environment for private investment. At the same time, there is the need for commitment on the part of government to the regulatory rules so that they are perceived as credible by investors. Where the legal regime is weak or nonexistent, private investment decisions will be adversely affected. No doubt, South Africa has developed one of the best legal and regulatory regimes for efficient procurement systems in the world and the project pipelines have greatly increased in recent times. This article therefore, examines the existing legal framework for Public-Private Partnership procurement in Malaysia and draws lessons from the South African legal regime. The article finally argues that for Malaysia to continue to attract and expand its investment atmosphere for the private sector there is the need for a clear and transparent legal and regulatory procurement framework which can seriously help in building confidence in the private sector and also guarantee their investment returns.
\end{abstract}

LL.B, LL.M, Ph.D, BL. Lecturer, Department of Business Law, Faculty of Law, University of Ilorin, Nigeria. Mobile Number: +2348061696375. E-mailmadekilekun@yahoo.com. Key research area- Public Procurement and PublicPrivate Partnerships.

** Retired Associate Professor, Faculty of Law, University of Malaya, 50603 Kuala Lumpur, Malaysia. He is still with the University of Malaya. Email: gancc@um.edu.my. Key research area: Administrative Law in the $21^{\text {st }}$ Century. 
Keywords: public-private partnerships, public procurement; infrastructure development, Malaysia, south Africa

\title{
KE ARAH KERANGKA PERUNDANGAN DAN KAWALSELIA UNTUK PERKONGSIAN AWAM- SWASTA DI MALAYSIA: PENGAJARAN DARIPADA PENGALAMAN DI AFRIKA SELATAN
}

\begin{abstract}
Bagi memastikan kerjasama berterusan dengan pelabur swasta tempatan dan asing di Malaysia, terutamanya dari segi peruntukan infrastruktur awam, kerajaan perlu membangunkan keupayaan perundangan dan kawalselia yang perkasa yang dapat membantu dalam menyediakan persekitaran yang stabil untuk pelaburan swasta. Pada masa yang sama, perlu adanya komitmen pihak kerajaan kepada kaedah kawalselia supaya boleh dipercayai oleh pelabur. Keputusan pelaburan swasta akan terjejas di mana rejim perundangan lemah atau tidak wujud. Memang tidak boleh disangkal bahawa Afrika Selatan telah membangunkan salah satu rejim perundangan dan kawalselia bagi sistem perolehan yang paling cekap di dunia dan projek kian bertambah sekarang. Makalah ini memeriksa kerangka perundangan masa kini untuk perolehan perkongsian swasta-awam di Malaysia dan mengambil pengajaran daripada rejim perundangan di Afrika Selatan. Makalah ini membuat kesimpulan bahawa Malaysia memerlukan satu kerangka perundangan dan kawalselia yang jelas dan telus untuk terus menarik dan memajukan persekitaran pelaburan untuk sektor swasta. Ianya akan membantu dalam membina keyakinan sektor swasta dan akan menjamin pulangan pelaburan.
\end{abstract}

Kata kunci: perkongsian awam-swasta, perolehan awam, pembangunan infrastruktur, Malaysia, Afrika Selatan 


\section{INTRODUCTION}

The ability of any government to effectively and efficiently acquire the resources for its social, economic and developmental goals is crucial and fundamental to its sustenance and development. An effective management and co-ordination of government procurement may therefore signal a factual test for government's effectiveness. ${ }^{1}$ A clear and sound procurement regime enhances steady development of the economy and also gives room for a systematic accomplishment of public development efforts. For developing economies, the legislative framework established for their procurement system has been identified as a major determinant of their access to sustainable development. $^{2}$

Malaysia's wealth of resources, dynamic economy as well as stable political system makes it one of ASEAN's leading lights. Peaceful political transition and firm commitments to democracy are really helping the country to gain the world's confidence. The country is attracting well-known international businesses that are currently investing in various sectors of the economy. ${ }^{3}$

However, in order to ensure a sustainable cooperation between the government and private investors in Malaysia especially in the procurement of public infrastructures, government urgently needs to develop a strong legal and regulatory capability which will provide a stable institutional environment for private investments.

This is because if the legal framework is weak or practically nonexistent, private investment responses to the development plan will be very slow and this could adversely affect economic development.

South Africa has undoubtedly developed one of the best legal and regulatory regimes for efficient public procurement system with

Benson Dele Oloworaran, The Law and Practice of Procurement in Nigeria (Port harcourt, Nigeria: Benuch Legal Consult, 2010), 1.

2 "Tunis Declaration on Public Procurement Reforms in Africa: Sustaining Economic Development and Poverty Reduction," accessed January 28, 2014, http://www.whoownswhom.co.za/public/africainc/trade_agreements/TunisDecla ration Final- Public Procurement Reform in Africa- English 3.pdf.

3 Malaysia's economic freedom score is $70.8 \%$, making its economy the $31^{\text {st }}$ freest in the 2015 index. Malaysia is a vital part of the East Asian manufacturing network. The business environment encourages the development of private sector. The country is ranked $8^{\text {th }}$ out of 42 countries in the Asia Pacific region, and its overall score is above the world and regional averages. Since 1957 when the country got her independence, there has been smooth political transition which has greatly helped in political and economic stability. 
stringent measures against inefficiencies and leakages. This article, therefore, examines the existing legal framework for Public-Private Partnership (PPP) procurement in Malaysia and draws valuable lessons from the South African legal and regulatory regime. The article argues that in order to ensure credibility, transparency and accountability in the procurement process, the Malaysian government needs to enact a robust and sustainable legal and regulatory framework that will improve transparency and accountability. The article concludes that only a constitutionally entrenched framework of measures and institutions, protected by certain entrenched principles can provide a solid basis on which an effective and sustainable infrastructure development can be assured.

\section{MEANING OF PUBLIC-PRIVATE PARTNERSHIPS}

According to Professor Sue Arrowsmith, the term Public Procurement refers to the entire process of government acquisitions. ${ }^{4}$ Public procurement refers to the purchase of goods and services by authorities in the market place from another legal entity, generally by contractual agreement. ${ }^{5}$

Public-Private Partnership is a procurement model which occupies a middle position between privatisation and traditional public procurement. ${ }^{6}$ The term "Public-Private Partnership" can be used to describe different arrangements involving the public and private sectors coming together to provide goods and services. In general terms, it means an arrangement or agreement involving a public sector authority and one or more private partners whereby the private partners perform or help in the provision of goods and

Sue Arrowsmith and Don Wallace, Regulating Public Procurement: National and International Perspectives (The Hague: Kluwer Law International, 2000), 2.

Peter Braun, "The Practical Impact of EU Public Procurement Law on PFI Procurement Practice in the United Kingdom" (University of Nottingham, 2001), 2.

6 It should be noted here that there are number of alternative names given to PPPs. In the United States of America, the term P3 is used; In Australia, it is called Privately Financed Project (PFP); In England and Japan, it is called Private Finance Initiative (PFI); In Malaysia and Nigeria, it is called Public Private Partnerships (PPP) ; In Indonesia and Egypt, it is called Private Sector Participation (PSP); It is referred to as Commercially Viable Utilities in India; In South Africa, it is called Partnerships while the World Bank prefers to use Privately Provided Infrastructure. 
services which were traditionally within the domain of the public sector authority. The term designates a variety of partnerships between the public authority and one or more private sectors for the designing, financing, construction, operation and maintenance of infrastructure that belong to the government with a view to recouping such investment from the direct users over a specified period of time. ${ }^{7}$

There are generally three socio-economic reasons why governments prefer to adopt the PPP model for the procurement of infrastructure. The first is because of the urgent need of infrastructure facilities. Secondly, there are serious cash constraints on the part of the governments and the third reason is because of the procurement failures of the past. Among the challenges that face the traditional procurement methods are lack of competition, lack of transparency, and inequality of treatment of the bidders. ${ }^{8}$ Also, some other hurdles to the public procurement process are bribery and corruption, dealing with cartel, environmental protection issues and non-availability of up to date technology..

In recent times, there is a worldwide movement in respect of Public-Private Partnerships. ${ }^{9}$ The main aim of this innovation is to introduce the effective functioning principles of the private sector into public administration. ${ }^{10}$ This move was necessitated by the need to reduce inefficiencies, wastages in public spending, lack of managerial skills and to attract private capital in the provision of public infrastructure.

Mubarak T. Adekilekun, "Quest for a Model Legal and Regulatory Framework for Public-Private Partnerships in Infrastructure Development: A Case Study of Three African Models and Core International Frameworks" (University of Malaya, 2014).

8 Braun, "The Practical Impact of EU Public Procurement Law on PFI Procurement Practice in the United Kingdom."

9 Darrin Grimsey and Mervyn Lewis, Public Private Partnerships: The Worldwide Revolution in Infrastructure Provision and Project Finance (Massachusetts, USA: Edward Elgar Publishing, 2007), 3.

10 Mr Etienne B Yehoue, Mona Hammami, and Jean-François Ruhashyankiko, Determinants of Public-Private Partnerships in Infrastructure (International Monetary Fund, 2006), 5. 


\section{IMPORTANCE OF A GOOD PROCUREMENT LEGISLATION TO A NATION'S DEVELOPMENT}

The importance of a good procurement regime cannot be overemphasised especially in the developing economies. In any nation, procurement of goods, infrastructure and services plays a vital role in budgeting, growth and national planning. An effective procurement regulation could be an impetus to vital international development cooperation/assistance. This position is predicated on the fact that a sound procurement system is adjudged an impulsion to prudent utilisation and management of government resources and by extension, of grants, loans, and grants received from development partners and donors. ${ }^{11}$

In fact, public procurement is the principal means through which governments especially in the developing countries meet vital developmental needs such as the provision of infrastructure and the supply of other necessary materials. ${ }^{12}$ In a country where there are no clear regulations, no doubt, public procurement will entail governmental exercise of enormous discretion. This is especially common in most developing countries where 'the ability to exercise discretion in the award of government contracts has been a source of valued political patronage' and procurement has been 'a means for the illicit transfer of funds from governmental to private hands. ${ }^{13}$

As a result of the fact that government purchases account for a major portion of government spending, therefore, procurement helps the people to understand government performance, accountability and transparency. In addition, although, there are no agreed estimates, public procurement expenditure in developing countries could be up to 20 per cent of the Gross Domestic Product (GDP). ${ }^{14}$ This is because taxes collected by the government, royalties on minerals and other natural resources, duties and other incomes accruable to the

11 J M Akech, "Development Partners and Governance of Public Procurement in Kenya: Enhancing Democracy in the Administration of Aid," NYUJ Int'l. L. \& Pol. 37 (2004): 829.

12 Ibid.

13 Patrick Low, Aaditya Mattoo, and Arvind Subramanian, "Government Procurement in Services," in Law and Policy in Public Purchasing: The WTO Agreement on Government Procurement, ed. Bernard M Hoekman and Petros C Mavroidis, vol. 16 (University of Michigan Press, 1997), 225-226.

14 Wayne A Wittig, "Building Value through Public Procurement: A Focus on Africa," International Trade Centre, 1999. 
public coffers are mostly expended to take care of acquisition of infrastructure, goods and services. ${ }^{15}$

Adoption of, and compliance to quality procurement policies may therefore, to a large extent, be a barometer for measuring the genuineness and performance of various other general priorities and policies embarked upon by the government to foster sustainable economic development. This is because the attainment of key government set targets depends on how successful and efficient procurement laws and policies are implemented. Public procurement policies are instrumental to enhancing all governmental apparatus to produce an effective transparent and productive administration.

\section{PUBLIC-PRIVATE PARTNERSHIPS IN MALAYSIA}

Public-Private Partnership initiative is not new in Malaysia. ${ }^{16}$ Some projects have been concessioned to the private sector to provide essential facilities. The privatisation policy of the Malaysian government was introduced in 1983 (under the Mid-term review of the Fourth Malaysia Plan) with the aim of increasing the roles of the private sector in the nation's socio-economic development. ${ }^{17}$ There were several projects especially highways that were built through what is similar to PPPs. Although, most of those projects were carried out under the privatisation policy using the Build, Operate and Transfer (BOT) scheme, the BOT approach has a semblance of the essential features of PPPs; pointing to the fact that PPP approach is adopted in the Malaysian tolled highway sector although the term PPP is not used in the respective government publications. The Malaysian government, especially during the reign of Tun Dr. Mahathir Mohammad facilitated the construction of many roads through concession to the private sector. The construction companies in the country have no doubt established a reputation as excellent road builders. Some of these roads are the North South Expressway with a concession period of 42 years; Kuala Lumpur-Karak Highway having a concession period of 38 years; the Kuala Lumpur City Road with a

\footnotetext{
15 Oloworaran, The Law and Practice of Procurement in Nigeria, 8.

16 Suhaiza Ismail and Fadhilah Asuhaimi, "Private Sector Involvement and Public Private Partnership (PPP) in Malaysia," 2013, 1.

17 "Official Portal of Public Private Partnership Unit (UKAS) - Background," accessed February 1, 2014, http://www.ukas.gov.my/en/latar-belakang.
} 
concession period of 26 years; Shah Alam Expressway with a concession period of 30 years and many others. ${ }^{18}$

\section{THE LEGAL AND REGULATORY FRAMEWORK FOR PPPS IN MALAYSIA}

The laws and regulations governing PPPs in Malaysia can be discussed under three sub-headings. These are the laws (Acts made by the Parliament), Guidelines, Instructions and Circulars.

\section{Statutes or Acts of Parliament}

There are two major laws enacted which regulate Public Procurement and PPPs in Malaysia. These are the Financial Procedure Act 1957 (Revised 1972) and Government Contracts Act 1949.

\section{The Financial Procedure Act of 1957}

This Act provides for the general control and management of the public finances of Malaysia. ${ }^{19}$ It set outs the financial and accounting procedures including the procedures for the collection, custody and disbursement of federal and state moneys as well as the purchase and disposal of government properties and such other matters connected thereto. The Act was amended in 1972 so as to empower the Minister of Finance to manage, control, supervise and direct all financial matters involving the federal government. Although, the provisions of the Act do not specifically focus on PPPs, nevertheless, they are very relevant to the way government goes about its fiduciary relationship and responsibility in public purchase and acquisition.

\section{The Government Contracts Act 1949}

This Act empowers ministers in the respective ministries to sign contracts on behalf of the government and to also delegate such powers which they can exercise to any officer in their respective

18 There are also the North Klang Straight Bypass with a concession period of 25 years, the North South Expressway Central Link having a concession period of about 29 years. The Kuala Lumpur Lumuth Highway Concession has a period of about 60 years.

19 "Malaysia's Government Procurement Regime," accessed February 2, 2014, http://www.treasury.gov.my/pdf/lain-lain/msia_regime.pdf. 
ministries to enter into any contract on behalf of the government. This Act was revised in 1973 which inter alia included the mandatory provision of getting the authorisation form signed by the respective heads of the ministries or Heads of States. ${ }^{20}$

\section{The Guidelines}

To complement the two statutes already mentioned above, the Malaysian Government issued both the Privatisation Guidelines and Public-Private Partnerships Guidelines to regulate both the Privatisation and the Public Private Partnerships programmes respectively.

\section{The Privatisation Guidelines}

From 1983 to April, 2009, the Privatisation guidelines was the major document put in place to regulate the privatisation programme in Malaysia. ${ }^{21}$ The first standardised guidelines which was issued in 1985 sets out the objectives of the policy, method of privatisation, as well as the implementation mechanism. Further in 1991, the government produced a Master Plan on the Privatisation Programme to explain the policy and strategy for privatisation.

In line with the policy, a Privatisation Section (formerly known as the Privatisation Special Task Force) was established which was under the Economic Planning Unit of the Prime Minister's Department (EPU, PMD). This section acts as the secretariat to the Privatisation Committee, which in turn is made up of various agencies working towards finalising and confirming the proposals on privatisation for the Ministers' Council's approval.

Under the privatisation scheme, projects were privatised using the BOT and concessions which are the main features of PPPs.

\section{The Public Private Partnership Guidelines}

Under the Ninth Malaysia Plan (9th MP), the Federal Government introduced the Private Finance Initiative (PFI) as an alternative procurement method for the provision and maintenance of infrastructures and other facilities, based on value for money and risk

\footnotetext{
20 Grace Xavier and Jason Chew, "Regulation of Public Procurement: General Principles and Guidelines with a Brief Overview of Procurement Principles Governing the Construction Industry in Malaysia," Construction Law Journal 28, no. 5 (2012): 404.

21 "Official Portal of Public Private Partnership Unit (UKAS) - Background."
} 
transfer. On 22nd April 2009, the government announced the establishment of a new unit under the Prime Minister's Department known as Privatisation and Private Finance Initiative Unit - PFI (currently known as Public Private Partnership - 3PU). ${ }^{22}$ This is the core agency that is vested with the responsibility of coordinating privatisation and public-private partnerships. ${ }^{23}$

\section{Instructions and Circulars}

Instructions and Circulars issued out by the Malaysian Government also contain provisions that regulate government procurements. These are the Treasury Instructions, Treasury Circular Letters and Federal Circular Letters.

\section{Treasury Instructions}

The provisions in the Treasury Instructions (TIs) complement the provisions of the Financial Procedure Act. The TIs also sets out the financial and accounting procedures including regulations on government purchases. They are issued to government agencies from time to time in case there are new changes in the procedures.

\section{Treasury Circular Letters}

This is issued by the Treasury Department of the Ministry of Finance from time to time with the purpose of clarifying, implementing, improving and amending certain rules, policies and procedures whenever they are deemed necessary by the government and the financial authorities concerned.

\section{Federal Central Contract Circulars}

Federal Central Contract Circulars are issued with the intention of letting the public be aware of the availability of some user items which can be centrally purchased. It provides the names, the supply coverage, the price, the mode and timeframe of the delivery.

\footnotetext{
22 Ibid.

23 "Public Private Partnerships in Malaysia," accessed February 1, 2014, http://www.pwc.com/my/en/assets/services/ppp-projects-in-malaysia.pdf.
} 


\section{An Analysis of the Legal Framework}

Despite the various laws and regulations put in place to regulate public Procurement and PPPs in Malaysia, a major hindrance militating against achieving effective Public Procurement has been absence of open and competitive bidding, fragmented procurement procedures, corruption and lack of transparency and accountability. ${ }^{24}$

In Malaysia, there is no detailed law that regulates competition in procurement. Competition entails that a sufficient number of bidders are invited to bid for the available contracts and ensures that government does not pay uncompetitive prices. The affirmative action policy between the Bumiputras, the Chinese and the Indians has long been a central development issue. This policy has prevented open competition based on equal access in public procurement process. This is achieved through preferential margins and quota restrictions. ${ }^{25}$ If only the qualified and most economically viable bidders have access to available contracts, the scope of corruption-induced awards will greatly reduce and it will also remove the restrictions to participation created against non-corrupt bidders. This affirmative action policy will therefore continue to discourage sound competitive trade practices and free participation in the economy.

Secondly, the procurement carried out in everyday practice is to a large extent undertaken in accordance with the provisions of the Treasury Instructions and Circulars. ${ }^{26}$ This is because the Financial Regulations Act and Government Contracts Act contain limited provisions relating to best practices in Public Procurement. ${ }^{27}$ They are

24 Khairul N. Adham and C Chamhuri, 'Transformation of Government Procurement in Malaysia: Directions and Initiatives' in Reforms and Transformation of Governance Part VII accessed 16 November, 2015, http://www.academia.edu/5333613/PART_VII_REFORMS_AND_TRANSFOR MATION_OF_GOVERNANCE_TRANSFORMATION_OF_GOVERNMENT _PROCUREMENT_IN_MALAYSIA_DIRECTIONS_AND_INITIATIVES.

These apply to all products acquired through small value purchases, which are confined to Malay-owned businesses. They also enjoy preferential margins up to $12 \frac{1}{2} \%$ for medium value and in some cases, high value tenders. What's more, up to $30 \%$ of the annual value of public works contracts must be awarded to Malay-owned businesses.

26 David Seth Jones, Key Failings in the Malaysian Public Procurement System and how they Can be Addressed by Greater Transparency. Policy Ideas N0.7 of the Institute for Democracy and Economic Affairs, October, 2013.

27 The Contract Act was enacted in 1949 while the latest revision carried out on the Financial Regulation Act was in 1972. 
not at pace with the current international best practices envisaged for Public Procurement. There is therefore the need to make them more comprehensive and in tune with the provisions relating to best practices especially in the UNCITRAL Model Laws on Public Procurement. $^{28}$

In addition to the above point, since the Treasury Instructions and Circulars were issued by the National Treasury, they may therefore be subject to changes at the will of the officer(s) that issued them. They may therefore not guarantee stability and certainty in the procurement process.

Another challenge facing procurement in Malaysia is corruption and lack of transparency. ${ }^{29}$ Publicity of laws, regulations, instructions, circulars and widely advertised tenders and quotations as well as public disclosure of the criteria by which technical and price proposals are evaluated are part of the measures to ensure transparency. Generally, if there is lack of transparency in the procurement process, then such process will be tainted with corruption. Therefore, comprehensive provisions on transparency will help in reducing corrupt practices.

\section{Case Study of Effect of Lack of Comprehensive Legal and Regulatory Framework}

The lack of comprehensive legal and regulatory measures has posed challenges to the implementation of some projects in Malaysia. For example, the Syabas water project which was initially concessioned for a period of 30 years is facing some challenges. ${ }^{30}$ As a result of the continued massive water rationing especially in the Klang Valley, the Federal Government and the State of Selangor initiated a

28 The United Nations Commission on International Trade Law (UNCITRAL) recognizes both PPPs and Public Procurement by adopting different legislative frameworks for the two. For PPPs, there is the UNCITRAL Model Law on Privately Financed Infrastructure Projects (PFIPs) 2003 and for public procurement, the Model Law on procurement of Good, Construction and Services was adopted in 1994.

29 Hassim A. Aliza et al, 'Factors Contributing to Ethical Issues in Project Procurement Planning : A Case Study in Malaysia : in $8^{\text {th }}$ International Conference on Construction and Real Estate Management accessed 16 November, 2015, http://eprints.qut.edu.au/38648/1/c38648.pdf.

30 "Corporate Profile» Syarikat Bekalan Air Selangor Sdn. Bhd.," accessed January 31, 2014, http://www.syabas.com.my/corporate/about-us-corporateprofile. 
Memorandum of Understanding to allow the latter to take-over and manage the four water projects from the concessioners. ${ }^{31}$ This was seen by many as a step towards the resolution of the Selangor water assets takeover saga which has generated much controversy since 2008 for at least 5 years. ${ }^{32}$ The Federal Government is optimistic that the process of handing over back to the state government will be accomplished before the end of year 2015 .

In respect of highway projects, some of the highway projects are becoming non-populist measures as a result of the flaws in the toll concession agreements. Instead of the present administration signing new road projects, the government is looking for ways of buying back the concession projects or building alternative roads to address the complaints of the users who have said that despite paying high tolls, they are still caught in serious traffic jams. ${ }^{33}$ While in some cases, the government has with the consent of the concessioners removed toll booths and in return government has given the concessioners contracts or jobs to make up for the short fall in earnings. ${ }^{34}$

In the same vein, lack of transparency in the procurement processes may lead to sub-optimal outcomes. A classical example of this is the construction project of the Matrade Building and the Navy Recruitment Training Centre in Malaysia which have both sparked serious allegations of corruption involving multi-billion Ringgits. Since the contracts were awarded, the Matrade projects have not yet been completed and the MRR2 project is facing a problem with the cracks that were found at the piling. ${ }^{35}$ Thus, it is important for planned procurement to be transparent to avoid having problems with the project implementation.

31 On $16^{\text {th }}$ May, 2014, the Federal Government announced its decision to postpone the enforcement of S. 114 of the Water Services Industry Act 2006 (WSIA) as there is no need to enforce it on Selangor's water utility firms, confirming the development when Three out of Four Concessionaires had accepted the takeover by the state government.

32 "An End to Malaysia Water Saga?" accessed November 7, 2015, http://www.mwa.org.my.

33 "Cover Story:How Toll Concessions Can Be Better Managed," The Edge Markets, July 26, 2006.

34 Ibid.

35 Aliza A. Hassim "' Project Governance: Ethical Decision Making in Project Procurement in the Malaysian Public Sectors" (Queensland University of Technology, 2012). 


\section{PUBLIC-PRIVATE PARTNERSHIPS IN SOUTH AFRICA}

South Africa is a developing country with a developed procurement regulation system. Like many developing countries, it has problem with corruption and has adopted the use of legal and regulatory measures among others ${ }^{36}$ to curb leakages in the procurement process. The regulation of procurement in South Africa has an interesting socio-political history. During the apartheid regime, public procurement was mostly used to protect the interests of the minority white $e^{37}$ and discriminated against the coloured and black-owned enterprises. In particular, "tender procedures were made to favour large white firms to the detriment of small emerging firms". ${ }^{38}$ At the end of the apartheid, it was resolved that public procurement would be utilised to democratise the economy and provide employment for the marginalised and disadvantaged individuals and communities such as the blacks and the coloureds. As a result of this, significant reforms were initially carried out through the implementation of interim measures within the existing legislative framework $^{39}$ and a Green Paper $^{40}$ was issued setting out the required legislative and policy changes. The major proposals of the Green Paper on using public procurement to democratise the economy and create access to opportunities to persons previously disadvantaged by the system have been implemented through legislations.

Public Private Partnerships began in South Africa in the mid1990s with the tolling of parts of the major national roads by the National Roads Agency as a result of budgetary constraints. ${ }^{41}$ The

37

Rogerson, C "Pro-Poor Local Economic Development in South Africa: The Application of Public Procurement" (2004) 15 (2) U. F. 180,181

38 World Bank, "Public and private sector procurement programmes and their contribution to emerging enterprises in South Africa" (Report prepared for the Workshop on Small, Medium and Micro Enterprise Development and Financing, 3 Nov. 1994); Sharp et al, Assessment of Public Sector Procurement to Small, Medium and Micro-Enterprises (1999).

39 Sope Williams-Elegbe, Fighting Corruption in Public Procurement: A Comparative Analysis of Disqualification Measures. Thesis submitted to the University of Nottingham for the Degree of Doctor of Philosophy. December, 2011.

404 Green Paper on Public Sector Procurement Reform (GG 17928,14 April, 1997). [Green Paper].

41 The N3 and N4 toll road Project that links South Africa to Maputo in Mozambique was a BOT project that gulped R2.6 Billion in 1997. 
first PPP project that was carried out in accordance with the National Treasury Regulation 16 was the Inkosi Albert Luthuli Central Hospital which was contracted to the private sector for 15 years under the Design, Finance, Build, Operate and Transfer (DFBOT). ${ }^{42}$ Under the arrangement, the private sector was to upgrade and manage the facilities and information technology of an 846-bed state-of-the-art referral hospital. The capital value of this project is put at US\$746 million. This hospital is well equipped and provides services to the people of KwaZulu Natal and the Eastern Cape Province. The general opinion has been that PPP through which this hospital was built has delivered a quality service which could not have been achieved by the government alone. ${ }^{43}$

Another successful project carried out under the PPP scheme in South Africa is the N3 and N4 toll road linking the South African provinces of Gauteng, Limpopo and Mpumalanga to the port of Maputo in Mozambique. Mozambique lacked the required funds to rehabilitate and maintain its own part of the N4 highway, the railway line and the ports which were long damaged as a result of the civil war that ravaged that country. ${ }^{44}$ As at 1997 , the total estimation of South Africa's requirement to fix its roads was estimated to be R37 billion, both governments were thus in need of funds to finance and maintain this all important infrastructure. As a result of this, the PPP approach was then resorted to, and with the cooperation of the private sector, the project became a reality.

Since the enactment of PPP laws in South Africa, over 300 of such partnership projects have already been executed at the national, provincial and municipal levels since the country became a constitutional democracy in $1994 .{ }^{45}$ The government recognises the fact that investment in the construction of roads, ports, railway

42 See PPP Quarterly, A publication of the PPP Unit, National Treasury South Africa. Number 28 of February, 2009.

43 Mubarak T. Adekilekun and C.C. Gan, "Public-Private Partnerships in Infrastructure Development in Africa: A Magic-Wand for Socio-Economic Growth and Development," in Symposium on Finding Solutions to Africa's Development (Pretoria, South Africa, 2013).

44 Civil war began in Mozambique in 1977 and ended in 1992. During this time, most of the critical infrastructure were damaged and this led to a serious infrastructure deficit.

45 Philippe Burger, "The Dedicated PPP Unit of the South African National Treasury," Policy, Finance \& Management for Public-Private Partnerships, 2006, 82-96. 
systems, electricity plants, hospitals and dams will contribute to faster economic growth and development.

\section{The Legal Framework for PPPs in South Africa}

South Africa has adopted a highly regulated and formal approach to public procurement and PPPs by entrenching constitutional provisions as well as binding legislations and regulations to achieve the procurement objectives. Similar to what is applicable in the United Kingdom, PPP procurement regulations occur at all the levels of government, i.e. Federal, Provincial and the Municipal Levels. The law and regulations developed for PPPs and other procurement models are clear and very comprehensive. These will be discussed under the following sub-headings -the Constitution, Statutes and Manuals as well as Regulations.

\section{The Constitution}

South Africa has developed a constitutionally entrenched framework and measures to regulate the ways and manner in which PPPs and other procurements are carried out. Specifically, Section 217(1) of the Constitution lays down the cardinal principles that all procurements must comply with in South Africa. It deals with the way and manner in which the state or any of its agencies engaged in the procurement of goods and services must adhere to. The section provides thus:

When an organ of state... contracts for goods or services, it must do so in accordance with a system which is fair, equitable, transparent, competitive and cost-effective.

According to the above quoted provision of the constitution, procurement process which includes the PPP procurement in goods or services must be done in a manner which is fair, transparent and cost effective.

In the same vein, Section 33(1) of the Constitution gives the citizens rights to fair administrative action that is lawful, reasonable and procedurally fair. This provision is to the effect that where any person feels that his or her rights have been adversely affected by any administrative action; such a person has the right to challenge this in a 
court of law. ${ }^{46}$ This provision applies to all procurements carried out by the government in order to promote efficiency in administration. Consequent upon this, the Parliament has enacted the Promotion of Administrative Justice Act (PAJA) 2000. This Act gives effect to the provision of Section 33 of the Constitution and other matters connected thereto.

\section{Acts of Parliament}

The South African Parliament has enacted various statutes which have direct provisions on Public Procurement and PPPs. These Acts include-
(A) Public Finance Management Act (PFMA) 1999
(B) Preferential Procurement Policy Framework Act 2000
(C) The Black Economic Empowerment Act, 2003
(D) Prevention and Combating of Corrupt Activities Act 2004
(E) Municipal Finance Management Act (MFMA) 2003

The above listed statutes will be discussed as follows:

\section{(A) Public Finance Management Act (PFMA) 1999}

This $\mathrm{Act}^{47}$ seeks to promote the principle of sound financial management with the aim of maximising service delivery and to effectively utilise the limited resources. The main objectives of the Act include modernising a system for the management of finances in the public sector; enabling public sector managers to manage the financial resources, and be held more accountable; ensuring the prompt provision of quality information; eliminating the waste and corruption in the use of public assets and other matters connected therewith.

This Act gives effect to the provisions of Sections $213^{48}$ and 215 to 219 of the Constitution of the Republic of South Africa. According to their combined provisions, there should be a national legislation enacted which shall among others establish the national treasury; provide for uniform treasury standards; prescribe the means and

\footnotetext{
46 There are no provisions for fair and administrative justice action under the Malaysian law.

47 Act No 1 of 1999. See the Government Gazette NO. 33059 dated 1 April, 2010.

48 This sector provides for the establishment of the National Revenue Fund into which all moneys received by the national government must be paid.
} 
procedure of ensuring transparency and expenditure control by the government; and also to set the operational procedures for borrowing, guarantees, procurement and oversight over the various national and provincial revenue funds. ${ }^{49}$

Specifically of note is the provision of Section 76 of the Act which empowers the Treasury in making regulations and or issuing instructions to the relevant institutions to which the Act applies to determine a framework that is appropriate for procurement and system which is fair, equitable, transparent, competitive and cost effective. Pursuant to this provision, the Treasury has issued Regulation 16 in accordance with the power vested on it. This regulation governs PPPs at the national level in South Africa.

\section{(B) Preferential Procurement Policy Framework Act 2000}

In accordance with Section 217(3) of the Constitution of the Republic of South Africa which provides for a framework in the implementation of the procurement policy contemplated in section 217(2), the legislature has therefore enacted the Preferential Procurement Framework Act. ${ }^{50}$ By the provision of Section 217(2) of the Constitution, governments and their agencies are empowered to use preferential procurement policies in order to advance or protect the interest of the blacks and coloured who were at the disadvantage end especially during the apartheid. Therefore, all state departments and agencies are required to put in place a sound policy regarding the preferential procurement and also to follow a standard procedure for procurement of goods and services. However, in adopting such a policy, the respective agencies must use a point system to ascertain whether the bids meet the contract criteria.

\section{(C) The Black Economic Empowerment Act 2003}

In an attempt to redress the economic effects of apartheid on the blacks in South Africa, the government has adopted a policy of Black Economic Empowerment (BEE) which is designed to be broad-based, inclusive and in accordance with the objectives of overall growth and development in accordance with the Black Economic Empowerment Act of 2003 and Section 76(4)(g) of the Public Finance Management Act, 1999 (PFMA). It is the requirement of this law that a Special

\footnotetext{
49 See the preamble to the PFMA.

50 See Act No 5 of 2000.
} 
Purpose Vehicle (SPV) should be structured in such a way as to demonstrate the black economic empowerment.

Specifically, the provisions relating to the code is contained in Module 2 of the National Treasury Public-Private Partnership Manual, issued in compliance with Section 76(4) (g) of the PFMA 1999. This code ${ }^{51}$ applies to all government departments ${ }^{52}$ and applies to all PPP transactions carried out in accordance with the National Treasury Regulation 16 to the PFMA. The code sets out government's policy instruments for achieving the BEE target. These are:

1. Direct black ownership of equity in the private party;

2. Black participation in the management and control;

3. Substantial subcontracting to black people and enterprises established by the blacks; and

4. Local socio-economic impact of such project on the black people.

Some observations need to be made regarding the term "Black People". It is pertinent to point out that "a black people" is "a generic term which means Africans, Coloureds and Indians". This is a term capable of broad and liberal interpretation. It cannot be given a narrow and literal interpretation. This is clearly amplified by the landmark case of $C A S A^{53}$ at the High Court in Pretoria in June 2008 which, inter alia, extended the protection of section 1 of the 2003 BEE Act to include the disadvantaged Chinese South Africans who could only be categorised as blacks because they are not whites.

Another matter of some constitutional importance may also be highlighted here. It must be emphasised that the affirmative action policy and law cannot be challenged for unconstitutionality on the ground that it causes reverse discrimination to the advantaged group despite their unpopularity. In South Africa, this is amply demonstrated by the famous case of Bato Star Fishing (Pty) Ltd $v$ The Minister of Environmental Affairs and Tourism and Others. ${ }^{54}$ Although this case is not a case of public procurement, its principle,

\footnotetext{
51 This simply connotes code of good practice.

52 See S.10 of the BBBEE Act.

53 Acronym for "Chinese Association of South Africa". Unfortunately this case was no reported.

54 Bato Star Fishing (Pty) Ltd $v$ The Minister of Environmental Affairs and Tourism and Others 2004 (4) SA 490 (CC).
} 
i.e., constitutional validity of affirmative action policy and law, is applicable here nevertheless. ${ }^{55}$ The BEE policy will be applied by the government departments and the PPP unit in two distinct phases of the PPP transaction. The first is in the appointment of a transaction advisor and the second, in the selection of a private party.

\section{(D) Prevention and Combating of Corrupt Activities Act 2004}

South Africa has adopted a number of initiatives with the aim of combating corruption especially in the public sector. ${ }^{56}$ In order to further prevent, combat, investigate and prosecute public sector corruption, the government harmonised the legislative framework on corruption and came up with the Prevention and Combating of Corrupt Activities Act. ${ }^{57}$ This act provides for stringent measures to combat corruption and the establishment of a register of persons and companies convicted for corruption and thereby preventing them from benefiting from public sector procurement. Once a name of a person or enterprise is registered in the list of corrupt persons, he or she is disqualified from participating in the PPP procurement process.

55 It should also be mentioned here that in Malaysia, in order to rectify the economic imbalances of the races, the government adopted a procurement policy which involved the participation of Bumeputra Entrepreneurs. The main objectives of the policy are to increase the Bumeputra share ownership in Malaysian companies and secondly, to use government procurement to bolster the system of preferences for the Bumeputras in the award of government contracts. According to McCrudden in his article, 'Using Procurement to Achieve Social Outcomes, Natural Resources forum, (2004) he posited that although, public procurement policy can be adopted to give room for redistributive and developmental goals, however, the core principles of Value for Money may be compromised and the requirements of competition and transparency will be highly reduced. He thereafter identified Four Problems that may be associated with procurement preferences in Malaysia. These are: political corruption; a decline of the entrepreneurial activities of the advantaged group; the likelihood that Bumeputra Contractors will sub-contract the projects already given to them and the increasing competition of contractors outside of Malaysia. It should therefore be stressed that this policy should be put to a halt once the aim of eradicating economic imbalances is achieved.

56 One of these is the Public Service Anti-Corruption Strategy which was launched to fight bribery, embezzlement, fraud, extortion, abuse of power, conflict of interest, insider trading, favouritism and nepotism in the public service.

57 See Act No 12 of 2004 vide the (Government Gazette 26311,28 April 2004). 
(E) Municipal Finance Management Act (MFMA) 2003

The Municipal Finance Management $\mathrm{Act}^{58}$ enacted in 2003 was made to ensure consistency in financial accountability for local spheres and it also provides for municipal PPPs and Treasury on feasibility. This Act provides in details for the three major tests of which PPP in South Africa is based. These are affordability, value for money and risk transfer. It also provides clarity for the PPP project cycle to be undergone by the parties to PPP contract. These are Inception, Feasibility Studies, Procurement and PPP contract management. Specifically, Section 120 of the MFMA provides that a municipal authority can enter into a PPP contract if it can demonstrate that the three tests mentioned above, i.e. affordability, value for money and appropriate risk transfer to the private party, are taken into consideration.

To ensure compliance and more accountability, the Minister of Finance in consultation with the Minister of Cooperative Governance and Traditional Affairs have by the powers conferred on them by Sections 168 and 175 of the Act make regulations to deal effectively with the matters bothering on municipal financial misconducts. These regulations ${ }^{59}$ also introduce measures to fight corruption in the public and private sectors through advocacy, strengthening the legal and policy frameworks and the proper implementation thereof.

\section{Manuals and Regulations}

These are the third layer in the hierarchy of laws and regulations applicable to procurement in South Africa. They were both issued by the National Treasury to complement the provisions of the Constitution as well as statutes as they relate to procurement practices in South Africa.

\section{The PPP Manual}

The South Africa's PPP Manual was issued by the National Treasury as a guide for best practices for government institutions and the private parties and all PPP practitioners. There are nine (9) different modules in the PPP manual and each of these modules is issued as a National Treasury PPP Practice Note in accordance with the Public Finance Management Act, 1999 (PFMA). This manual and the

\footnotetext{
$58 \quad$ Act No 56 of 2003.

59 See Notice 556 of 2012.
} 
Standardised PPP provision issued by the National Treasury as Note 01 of 2004 are complementary and should be read together. National Treasury's PPP Manual mainly deals with what are expected to be done during the Project Preparation period. Different approvals including approvals I, IIA, IIB and III must be made in accordance with the provisions of the manual. ${ }^{60}$

The manual is based on the past project experience of the country and also on the international best practice. It sets standards as to the risk-assessment whereby the government is required to prioritize affordable projects that are best suitable for the PPP project for quality public service delivery. Also, this manual also ensures the achievement of the black economic empowerment programme in PPPs, not only in ensuring equality and fairness in the selection and management of the private sector party, but also in subcontracting the projects so as to have local socio-economic impacts on the black people. It also stipulates what approval needs to be sought and at what stages such approvals are required.

\section{Treasury Regulation 16}

This regulation was issued by the National Treasury in accordance with Section 76 of the Public Finance Management Act 1999. This is the main regulation that governs PPP in South Africa. This regulation regulates the powers of the project officers and the accounting officers. It also provides for the stages in the PPP cycle; what approvals are to be obtained and also at what stage are the approval to be obtained.

\section{COMPARISON BETWEEN THE MALAYSIAN AND SOUTH AFRICAN PROVISIONS}

This part will show the basic similarities and differences in the procurement provisions within the two jurisdictions. This will be discussed in terms of underlying principles, dispute resolution and comprehensiveness of the legal and regulatory framework.

60 These are called Treasury approvals TAs and are issued by the Procurement Officers of the National Treasury in compliance with Regulation 16. These approvals must be sought and obtained during the procurement phase. Without these approvals, the project officers cannot go ahead with the projects. 


\section{Procurement Principles}

Under the Malaysian Provisions, the principles upon which the government procurement are said to be based are public accountability, transparency, value for money, open and fair competition and fair dealings. ${ }^{61}$ These principles apply to both public procurement and PPPs. However, apart from the fact that these principles were stated as policies, they are neither entrenched in the Constitution nor provided for in any statute. Also, the procedures for achieving the stated principles were not laid down. This is because, it is one thing to state the procurement principles, and it is another thing to provide for means of achieving the core procurement principles. The great anti-corruption activist ${ }^{62}$ put the reason why good procurement legislation is important in Malaysia thus:

Public Procurement is the single most important source of corruption in any country, including ours. This crucial process remains a great mystery to the public at large because it is shrouded in secrecy... The mystery is heightened by the Official Secret Act (OSA)...The OSA hides a multitude of sins and it is an impediment to transparency...The government finds comfort and safety by hiding all of its more questionable and corrupt actions that cannot stand close scrutiny behind the OSA. As we know, without transparency, there is no accountability.

In South Africa, the principles enjoy constitutional backing which made them mandatory for all authorities and persons to observe. Some of these principles will be discussed in seriatim:

(a) The Constitution, National Treasury Regulation and other relevant legislations set out the procurement procedures in South Africa. This regime also applies to PPP transactions. S.217 of the Constitution provides thus:

The requirement for a system that is 'fair and equitable' in Section 217(1) of the constitution can be construed as requiring the

\footnotetext{
61 "Malaysia's Government Procurement Regime."

62 Tunku Aziz, Procurement, a call for transparency accessed November 82015 http://www.themalaysianinsider.com/opinion/tunku-aziz/article/Procurement-Acall-for-transparency.
} 
adoption of a system that is fair without unjustifiable preferences and discrimination. ${ }^{63}$

Section 217(1) of the Constitution ${ }^{64}$ also requires that the procurement system should be 'transparent'. Transparency has been interpreted as requiring publicised contracts; rule-based decision making and opportunities for verification and enforcement; and disclosure of the rules governing procurement in general and governing specific procurements. ${ }^{65}$ It was posited that the constitutional provisions on transparency were necessitated as a response to the culture of secrecy in the apartheid era, which was adopted in restricting the access of blacks to economic opportunities. ${ }^{66}$

The principles of competition and cost-effectiveness which were entrenched in S.217 (1) of the Constitution complement each other. Competition entails that a sufficient number of bidders are invited to bid for the available PPP contracts, ensuring that government does not pay uncompetitive prices. Competition in procurements will definitely support the anti-corruption efforts, this is because, if only the qualified and most economically viable bidder have access to available contracts. This will reduce the number and scope of corruption-induced awards and remove the restrictions to participation created against non-corrupt bidders. Cost- effectiveness on the other hand can be construed to mean an obligation to obtain value for money for the project. This suggests that the procuring agencies should seek to get the best bargain and the most advantageous contractual terms. ${ }^{6}$

(b) Also, PPP procurement is subject to the Competition Act, $1998 .^{68}$ This Act seeks to encourage competition in the bidding process

63 Sope Williams-Elegbe, "Fighting Corruption in Public Procurement: A Comparative Analysis of Disqualification or Debarment Measures" (Hart Publishing, 2011), 85.

64 See the 1996 Constitution, Act No 108.

65 Sue Arrowsmith, "Towards a Multilateral Agreement on Transparency in Government Procurement," International and Comparative Law Quarterly 47, no. 04 (1998): 793-816.

66 Ron Watermeyer, "Transparency within the South African Public Procurement System," in Unpacking Transparency in Government Procurement, ed. Bernard M. Hoekman, 2004, 173.

67 Williams-Elegbe, "Fighting Corruption in Public Procurement: A Comparative Analysis of Disqualification or Debarment Measures."

68 As Amended by the Competition Amended Act, No 35 of 1999. 
especially in PPP procurement in order to promote economic development, efficiency and an efficient functioning economy. Also, among the intendment of the Competition Act is to open the economy to a greater number of South Africans by encouraging sound competitive trade practices and eradicating restraints on the full and free participation in the economy. Specifically, Section 81 of the Act provides that the Act binds the state.

(c) Section 33(1) of the Constitution gives every person ${ }^{69}$ the rights to fair administrative action that is lawful, reasonable and procedurally fair. This section states as follows:

(1) Everyone has the right to administrative action that is lawful, reasonable and procedurally fair.

(2) Everyone whose rights have been adversely affected by administrative action has the right to be given written reasons.

(3) National legislation must be enacted to give effect to these rights, and must -

(a) Provide for the review of administrative action by a court or, where appropriate, an independent and impartial tribunal;

(b) Impose a duty on the state to give effect to the rights in Subsections (1) and (2); and Promote an efficient administration.'

This Act provides for reasonableness, lawfulness and procedural fairness in all dealings or transactions with the government or any of its departments or agencies. Procedural fairness relates to the principles of fairness going far beyond the common law principles of audi alteram partem and nemo judex in causa sua. ${ }^{70}$ Therefore, where a person's right to administrative justice has been adversely affected, such a person has a right to be given written reasons. ${ }^{71}$ These reasons must be adequate, relevant, and cogent and must relate to the administrative action under scrutiny. The provisions on the right to be given written reasons are

69 This may either be natural or juristic person. The latter will include a company or corporation or any commercial entity set up to operate a business enterprise.

70 See the provisions of Sections 3 and 4 of PAJA 2000 and also the rules and regulations made under PAJA.

71 See the provisions of $\mathrm{s} 5$ of the PAJA. 
arguably meant to promote a more transparent, publicparticipatory, democratic and efficient administration. On the other hand, reasonableness relates to the substantive aspects of the ultra vires doctrine, by which a court is afforded the opportunity to investigate the justification of administrative actions. This fundamental right to just administrative action is evolving rapidly since the enactment and application of the Promotion of Administrative Justice Act 2000 (PAJA).

This $^{72}$ has been identified, developed and showcased by the Constitutional Court of South Africa and it has become a rich source and the new hallmarks of the country's administrative law going far beyond Wednesbury Review. The right to just administrative action applies to all exercises of public power, and its contents generally include the concepts of lawfulness, rationality, procedural fairness and even the giving of reasons by administrators. ${ }^{73}$ The three grounds of judicial review under Section 33 of the Constitution and the laws enacted thereunder apply equally to public procurement inclusive of PPPs. Each ground may operate independently and separately. ${ }^{74}$

In Leon Joseph \& others V. City of Johannesburg \& others ${ }^{75}$ the Constitutional Court held that the provision of the Promotion of Administrative Justice Act 3 of 2000, requires that government agencies and institutions to afford all citizens a procedure that is reasonable and fair before taking a decision that will materially and adversely affect their rights.

It follows, therefore, that all administrative actions or decisions taken in a PPP procurement process must comply with the mandatory criteria set out and prescribed by law. There should be openness, responsiveness and accountability in the decision-making process by all the governmental institutions. All bidders at every stage of the procurement process must be given an equal opportunity to compete and bid for the contract.

72 The right to just administrative action.

73 See Masetlha v. President of the Republic of South Africa 2008 (1) SA 566(CC), para78;Louis J Kotzé, "The Application of Just Administrative Action in the South African Environmental Governance Sphere: An Analysis of Some Contemporary Thoughts and Recent Jurisprudence," Potchefstroom Electronic Law Journal/Potchefstroomse Elektroniese Regsblad 7, no. 2 (2009).“

75 In Leon Joseph \& others V. City of Johannesburg \& others CCT 43/09. 


\section{Publicity and Information Disclosure in Public-Private Partnership and Procurement}

It must be stated here that currently, Malaysia does not have a law that guarantees the right to information. This law is very important because it affords the general public the right to know what is taking place in public offices and the ability to monitor the implementation of policies and procurement procedures. The law will afford the people the opportunity to know the activities of the government, agencies and the officials with respect to the allocation of public resources. This is a potent power to fight corruption. It is trite that corrupt practices flourish in darkness and secrecy, so any attempt that is aimed at opening governments and their agencies to public scrutiny is very likely to advance anti-corruption efforts. ${ }^{76}$

In order to boost transparency and prevent corrupt practices in the award of procurement contracts in Malaysia, the Prime Minister, Dato' Sri Najib Tun Razak launched the myprocurement website on $1^{\text {st }}$ of April, 2010. This portal provides for tender advertisement and names of successful bidders. ${ }^{77}$ In order to further enthrone integrity in procurement, it is the requirement that bidders will have to sign a declaration upon submission of the bids. The government has also introduced e-procurement as part of the eight projects under the egovernment flagship since 1997. This e-procurement links the government and suppliers wishing to procure goods or services by providing electronic means to browse the catalogue advertised by the suppliers.

In South Africa, the right of access to information is protected under the South African Constitution, ${ }^{78}$ the Promotion of Access to Information Act (PAIA), ${ }^{79}$ Standardized Public-Private Partnership

76 Hector o. Boham, "FREEDOM OF INFORMATION ACT: A POWERFUL WEAPON AGAINST CORRUPTION;," accessed November 24, 2013, http://www.modernghana.com/news/454616/1/freedom-of-information-act-apowerful-weapon-again.html.

77 Cheong May Fong, "Goals of Public Procurement: A Fine Balancing Act for Malaysia," Journal of Malaysian and Comparative Law 38, no. 1 (2013): 19.

78 See s 32, which provides for the right of access to information held by the state, and by any other person (including private bodies), where the information is necessary for the protection of any rights. The right also makes provision for legislation (PAIA) to be passed to give effect to the constitutional right. Act No 2 of 2000. 
Provisions ${ }^{80}$ and the Public-Private Partnership manual. ${ }^{81}$ This piece of legislation was enacted in response to a corresponding section in the Bill of Right. The Preamble to the PAIA gave a backdrop upon which the law was passed. It states:

The system of government in South Africa before 27 April 1994 ... resulted in a secretive and unresponsive culture in public and private bodies which often led to an abuse of power and human rights violations.

Section 32 of the South African Constitution provides:

Everyone has the right to have access to;

(1) Information which the government has; and

(2) Information that someone else has if they need to protect any of their rights.

This constitutional right is rooted on the need to promote human rights by giving individuals the right of access to information that are necessary for protecting their rights, promotion of a human rights culture and ensuring social justice. The Act further seeks to foster a culture of transparency, accountability, and the efficient governance of public and private bodies. ${ }^{82}$ Therefore under the Constitution, information that a person may have access to is not only limited to the information that is within the domains of government, but rather extends to such information from an individual or a private body or entity, provided that that information is needed in order to protect the person's right.

In Brümmer v Minister for Social Development and Others, ${ }^{83}$ The Constitutional Court explained the importance of the constitutional right of access to information thus:

The importance of this right . . . in a country which is founded on values of accountability, responsiveness and openness, cannot be gainsaid. To give effect to these founding values, the public must

80 See generally Clause 95 of the Standardized Provision.

81 All these legislations contain separate provisions on the right of access to information.

82 See s 9(e), which gives the following as part of the PAIA's objects, i.e. "...generally, to promote transparency, accountability and effective governance of all public and private bodies..."

83 [2009] ZACC 21; 2009 (6) SA 323 (CC); 2009 (11) BCLR 1075 (CC). 
have access to information held by the State. Indeed one of the basic values and principles governing public administration is transparency. And the Constitution demands that transparency 'must be fostered by providing the public with timely, accessible and accurate information.

The Standardised PPP Provisions and the PPP Manual lend credence to the constitutional access to information. These provisions gave an elaboration on the application of information disclosure and treatment of confidential information in PPP contracts. ${ }^{84}$ The standardised provision also categorically states the obligation on the part of the private entities to make available any information that is required. However, in cases of sensitive commercial information, little information can be withheld due to public reasons. ${ }^{85}$

\section{Dispute Resolution Mechanism}

There is no doubt that mechanism for handling PPP disputes contribute to transparency and accountability by ensuring that the provisions of the law and other requirements are strictly adhered to. In addition, an effective dispute settlement mechanism ensures that all parties in the transaction are given a fair and equitable opportunity in the procurement process. $^{86}$

There are no standardised provisions in the dispute resolution mechanism in Public Procurement in Malaysia. This is very important because it is a matter of great interest to any intending private sector developer. The Finance Ministry in Malaysia is so powerful that it is seen as the alpha and the omega and can set down procurement rules at will. McCrudden and Gross have put it succinctly thus;

[While] significant mechanisms exist, which allow the Finance Ministry to monitor and control the government procurement

84 "Disclosure of Project and Contract Information in Public-Private Partnership Contracts" (World Bank Institute), accessed November 17, 2013, http:/wwwwds.worldbank.org/external/default/WDSContentServer/WDSP/IB/2013/03/28/ 000333037_20130328103832/Rendered/PDF/762780WP0Box370osure0of0Proj ect0PPP.pdf.

85 See Clause 95.1, of the Standardized PPP Provisions.

86 A.B Adjei, "Challenges in the Handling of Procurement Complaints: Ghana's Experience," Journal of Malaysian and Comparative Law 38, no. 1 (2011): 1. 
activities of other governmental entities to ensure that they obey Treasury-issued government procurement regulation...remedies for aggrieved tenderers who believed that the Finance Ministry or another government entity has wronged them at any of the various stages of the tendering process are practically non-existent. Further, the more general controls, which ensure in a liberal democracy that the actions of an administrative agency will be contained within bounds of the powers granted to it by democratically elected bodies, are similarly absent. Thus, the Finance Ministry is practically free to rule government procurement in Malaysia according to its discretion $^{87}$

The above quoted provision shows that remedies for a breach of procurement principles are almost non-existent in Malaysia.

In South Africa however, the Arbitration Act, ${ }^{88}$ Module 6 of the National Treasury PPP Manual and the Standardised provision ${ }^{89}$ prescribe a detailed procedure for resolving dispute in PPP and Public Procurement. It is therefore important for the parties to include this in the PPP Agreement. The regulation requires that before a PPP dispute is taken to court, alternative means of settling disputes like informal conciliation must first be attempted because these modes will fasttrack the resolution of the dispute by expert adjudicators. Also, resolving the dispute through an alternative means will also settle the dispute amicably. This is because the mode and procedure adopted is by a consensus of the two parties rather than by imposition of the law by the court. South Africa has therefore provided a detailed dispute resolution method which is very important especially in commercial contracts like that of PPPs.

\section{PUBLIC PROCUREMENT AND PUBLIC-PRIVATE PARTNERSHIP REGULATIONS IN THE ASEAN REGION}

In order for the ASEAN countries to be a leading light and become an investment destination in the world, the 10 member countries need to improve interconnectivity and develop proper regulations for PPPs

87 Christopher McCrudden and Stuart G Gross, "WTO Government Procurement Rules and the Local Dynamics of Procurement Policies: A Malaysian Case Study," European Journal of International Law 17, no. 1 (2006): 151.

89 See Part 86 of the Standardised Provision. 
with the aim of boosting their critical infrastructure. In April 2013, the governments of the ASEAN countries issued Infrastructure Intelligence Report where the member nations expressed their readiness to interconnect the region by $2015 .{ }^{90}$ Both the ASEAN Economic Community Blueprint and the Master Plan on ASEAN Connectivity which were adopted in 2007 and 2010 respectively provide for plans and programmes to be pursued in order to link these all important physical infrastructure within the region.

However, for the region to be able to successfully finance these infrastructure projects, it was estimated that the governments of the member states need to raise $\$ 600$ billion over the next 10 years. ${ }^{91}$ No doubt, the governments alone lack the resources to finance and execute these critical developmental projects. Both the ASEAN Master Plan Connectivity and the Economic Blueprint have therefore identified PPP initiative as a solution in closing the infrastructure funding gaps and delivering high-quality infrastructure services.

It must be pointed out clearly here that if the ASEAN countries would achieve this development initiative, they must develop robust legislation and create enabling environment for the private sector to come in. Procurement and PPP regulations in the region are generally very poor except for Singapore. This is because, most of the countries within the region use mere guidelines rather than clear and comprehensive provisions to regulate their procurement system. Malaysia, ${ }^{92}$ Thailand, ${ }^{93}$ Indonesia, ${ }^{94}$ Vietnam,,${ }^{95}$ Laos and few others

90 "INFRASTRUCTURE INVESTOR: ASEAN An Intelligence Report" (PEI Alternative Insight, April 2013).

91 Ibid.

92 As earlier discussed in this paper, Malaysia does not have a robust legislation for procurement and PPPs yet. It still operates a mere guidelines.

93 Thailand is also currently being governed by mere regulations. The main Procurement legislation $\mathrm{n}$ Thailand is the Regulation of the Office of the Prime Minister (OPM) on Procurement which was first enacted in 1992 and had six series of amendments the lastest being that of 2002. For further reading on this, see Sirilaksana Khoman, "Issues and Challenges of Accession to the GPA by Developing Economies: A Study of Thailand," Journal of Malaysian and Comparative Law 38, no. 1 (2013).

94 PPP Policy and Regulation was made in Indonesia in 2011, up till now, there is no standard legal framework on same. See further http://www.oecd.org/gov/regulatory-policy/47377646.pdf.

95 The Ministry of Planning and Investment in Vietnam has also released the PPP Pilot Regulation in April 2010."Latest Draft of Pilot Public Private Partnerships Regulations Released -" (Vietnam Briefing News), accessed February 14, 2014, 
are some of those countries with no comprehensive procurement legislation.

Despite the high level of development in the countries within the European Community (EC), the community still considered it expedient to adopt the European Commission's Directives on the Award of Concessions in December 2011. It was discovered that the lack of legal certainty has occasioned serious distortions in the functioning of the internal market and was hindering the access of European businesses. Not only that, it also resulted in lack of efficiency in the way and manner businesses were carried out. In the explanatory memorandum of the Directive of the European Parliament and of the Council on the award of concession contracts, ${ }^{96}$ the reasons for the Community's intention to adopt a single legislative framework were stated thus:

In the context of severe budgetary constraints and economic difficulties in many EU Member States, efficient allocation of public funds is of particular concern. An adequate legal framework for the award of concession contracts would favour public and private investment in infrastructure and strategic services at best value for money. The potential of a legislative initiative on concession contracts to create a supportive EU framework for PPPs was singled out in the Commission's 2009 communication on Mobilising private and public investment for recovery and long term structural change: developing public-private partnerships.

The main aim of this initiative therefore is to reduce the uncertainty surrounding the award of concession contracts which can result into great benefits to both the public authorities and the private economic operators in the development of infrastructure. A clear legal framework will also allow all economic operators within the EU effective access to the market. The countries of the ASEAN region can also learn lessons from this.

http://www.vietnam-briefing.com/news/latest-draft-pilot-public-privatepartnerships-regulations-released.html/. 


\section{LESSONS FROM THE SOUTH AFRICA'S PUBLIC-PRIVATE PARTNERSHIP FRAMEWORK}

South Africa has adopted a highly regulated and formal approach to public procurement and PPPs through Constitutional provisions as well as binding legislation and regulations to achieve the procurement objectives. The Administrative Law in South Africa has developed at an unprecedented manner making the country to be one of the best in the world in terms of administrative laws and regulations especially with provisions on the administrative justice action.

South Africa has also incorporated various anti-corruption measures into its procurement regulations generally, and the effects of such mechanisms on the machinery of government will be great (William-Elegbede 2011). ${ }^{97}$ An example of this is the Prevention and Combating of Corrupt Activities Act. Furthermore, the basic principles of transparency, accountability, fairness, cost-effectiveness and publicity have constitutional backings and other supporting legislations. These are very important principles that guide all procurements.

The provisions relating to dispute resolution in the South Africa's PPP are very comprehensive and effective. This is important in order to attract the private sector to develop public infrastructure. The establishment of a dedicated PPP Unit within the national treasury helps in understanding and appreciating the budgetary implications of PPPs. This is because PPP procurement is linked to the finances of government departments. Where the power to regulate the PPP is vested in a department which does not really understand these financial intricacies, this may lead to financial imbalances. The Establishment of the PPP units at the Municipal and Provincial ensures that PPP projects are implemented at the Municipal and provincial levels. This will increase the PPP deal flow and drastically increase the pace of development at these levels.

A clearly defined evaluation and procurement processes enables the bid evaluation and the procurement to be transparent to a larger extent. The delivery of a PPP project that is well structured and which is in line with the principles of affordability, value for money and sufficient risk transfer is the ultimate objective of the South African PPP programme.

97 Williams-Elegbe, "Fighting Corruption in Public Procurement: A Comparative Analysis of Disqualification or Debarment Measures." 
The government must first explore the possibility of carrying out a project under the public procurement before contracting it under PPP. It is not all projects that fit into PPPs. It is only an alternative means of building infrastructure where public procurement will not be suitable. Finally, the PPP Unit which coordinates and renders technical assistance to government departments should be more equipped with skilled staff. This will help in increasing the pace at which South Africa rolls out more PPP project.

\section{CONCLUSION AND RECOMMENDATIONS}

Today, governments, especially those of developing nations have not fully grasped the opportunities provided by the private sector which are: the availability of large capital to meet the growing needs of infrastructure projects; competence and efficient management of resources; skills and access to advanced technology; as well as transparency and accountability to drive a nation to achieve sustainable socio-economic development. The paradigm shift is now from 'government-providing' to 'government enabling' approach in the provision of infrastructure.

However, for governments to be able to effectively lure the private sector into providing these basic infrastructural facilities, government should ensure that it has provided a clear legal and regulatory framework for PPPs to thrive. This is because legal certainty and regulatory stability are sine qua non to a successful PPP programme. These will go a long way in helping nations to achieve sustainability in PPP programmes.

The existence of clear and constitutionally entrenched legal framework in South Africa is helping to boost the number of projects being carried out under the PPP programme in the country. As stated earlier in this paper, more than 300 of such projects have been carried out in the country.

Unlike in South Africa where the laws and regulations are very clear and well communicated, the existence of PPPs in Malaysia is mainly regulated by mere policies and guidelines. ${ }^{98}$ Malaysia and other nations in the ASEAN region are encouraged to enact clear and

98 Ervina Alfan, "The Malaysian Public-Private Partnership (PPP): Financing the Tolled Highway Projects," Asian Journal of Business and Accounting 3, no. 2 (2010): 121-43. 
robust legal and regulatory framework that can propel the countries to the Promised Land. This is the only means through which the nations can achieve the objectives of efficient and transparent procurement regime. This paper therefore recommends the following for a sustainable legal and regulatory framework for PP in Malaysia and the ASEAN region:

1. A comprehensive legal and regulatory framework is very essential in sustaining PPP programmes in Malaysia and other ASEAN Countries. The existing legislative frameworks are not comprehensive enough to ensure a successful PPP programme. There should be certainty in the law on PPPs in order to clarify and define the obligations of the contracting parties and the regulatory agencies. In the absence of a sound and comprehensive legislative initiative, the rules on the definition and award of PPP contracts and other vital issues will emerge from decisions of courts, leaving legal uncertainty to persist and its attendant price and protracted litigation.

2. The law and policy regulating PPPs in Malaysia as presently constituted do not support the drive to fully ensure fairness, transparency and accountability which are very cardinal in any procurement process. Transparency and accountability enthrone integrity in the PPP procurement process.

3. Information is also another very viable tool to monitor procurement processes. The freedom of information law should be enacted to afford Malaysia access to information about the activities of government, agencies and the officials with respect to the allocation of public funds and resources. This is a potent power to fight corruption.

4. ASEAN governments are encouraged to adopt a uniform legal and regulatory regime to address PPPs transactions within the countries of the region. Despite the high level of infrastructure development in Europe, the European Commission, in a bid to have a single legal and regulatory regime, has adopted a uniform legislative framework to govern PPP contracts in the community. This will help the European Commission to further boost growth and strengthen confidence in the investors. Presently, the award of 
PPP contracts within the ASEAN region is subject to a limited number of secondary provisions which are applicable in the few countries that have legislative framework for PPPs. This gap will limit the access of ASEAN businesses to international borders.

5. The establishment of an effective and efficient regulatory authority that is insulated from political influence is also very cardinal to a successful PPP programme. 